\title{
FUTURE PROPERTY AND THE TORRENS SYSTEM
}

\author{
GLEN ANDERSON*
}

Since at least the seventeenth century, courts of equity have upheld the assignment of future property for valuable consideration. Despite this long lineage, however, there has been almost no scholarly analysis of how these principles might interact with the Torrens system. The present article addresses this deficiency. Generally, it argues that there are no reasons why principles of future property cannot be fully subsumed within the Torrens system.

\section{INTRODUCTION}

The present article investigates how assignments of future property ${ }^{1}$ might interact with the Torrens system. In doing so, it probes the intersection of two divergent forces: equity's pre-modern jurisdiction grounded in conscience and substance, and the relatively contemporary Torrens system, based on registration, administrative uniformity, and title certainty.

The article argues that there are no reasons why principles of future property cannot be fully subsumed within the Torrens system. More specifically, it contends that well established features of the Torrens system, such as caveats and the in personam exception to indefeasibility, would be readily applicable to future land ${ }^{2}$ transactions and disputes.

The article consists of four main sections. Section II enumerates the general principles applicable to the assignment of future property. Section III examines aspects of the assignment of future land common to all land title

\footnotetext{
* BA (Hons) BA/LLB(Hons) PhD (Macq) Lecturer in Law, University of Newcastle, Australia.

${ }^{1}$ Meaning property which is yet to be acquired by the assignor, and which the assignor has no legal right to acquire at the time of the assignment. Future property is only assignable in equity for valuable consideration. The principles of future property, and their applicability to land, are discussed in further detail infra.

${ }^{2}$ Meaning land which is assigned pursuant to principles of future property.
} 
types. Section IV specifically analyses the interactions between future property and the Torrens system. Most importantly, this section outlines the case for a new in personam claim: failure to assure future Torrens land. Section V synthesises all aspects of the preceding discussion and concludes that there are no barriers to the assignment of future land within the Torrens system.

\section{General Principles}

'Future property'3 can be defined as, 'property which does not exist or in which the assignor at the time of the assignment has no proprietary interest. ${ }^{4}$ Or as defined by Heydon, Leeming and Turner:

By way of the terms 'future property', '(mere) expectancy', 'spes' or 'spes successionis' what is generally meant is a right or title which one has not yet acquired and lacks a legal right to acquire but which one may acquire in the future. ${ }^{5}$

These definitions do not capture property anticipated as the result of a procedure of a chattel; this is instead termed 'potential property' and is considered to have a present existence, however counter-intuitive this might seem. ${ }^{6}$

A legal assignment of future property is nugatory ${ }^{7}$ as the law historically refused to give recognition to 'prophetic conveyance[s].' ${ }^{8}$ An assignment of future property can thus only be made in equity. ${ }^{9}$ For this to occur, however, there must be valuable consideration to bind the assignor's

\footnotetext{
${ }^{3}$ Also referred to as 'after acquired property'.

${ }^{4}$ Akron Tyre Co Pty Ltd v Kittson (1951) 82 CLR 477, 484 (Latham CJ).

5 JD Heydon, MJ Leeming and PG Turner, Meagher, Gummow and Lehane's Equity Doctrines and Remedies (LexisNexis Butterworths, $5^{\text {th }} \mathrm{ed}$, 2015) 256.

${ }^{6}$ JF Keeler, 'Some Reflections on Holroyd v Marshall' (1967-70) 3 Adelaide Law Review 360, footnote 1. For judicial consideration of potential property, see Norman $v$ Federal Commissioner of Taxation (1963) 109 CLR 9, 25 (Windeyer J); Re Puntoriero; Ex parte Nickpack Pty Ltd (1991) 104 ALR 523, 529-30 (Einfeld J).

${ }^{7}$ Chauncy v Graydon (1743) 2 Atk 616, 621 (Lord Hardwicke LC); Robinson v Macdonnell (1816) 5 M \& S 228, 235-36 (Lord Ellenborough CJ); Holroyd v Marshall (1862) 10 HLC 191; (1862) 11 ER 999, HLC 209 (Lord Westbury LC), HLC 216 (Lord Chelmsford); Lloyd $v$ European and North American Railway Co (1878) 18 NBR 194, 206-07 (Allen CJ); Akron Tyre Co Pty Ltd v Kittson (1951) 82 CLR 477, 484 (Latham CJ); Norman v Federal Commissioner of Taxation (1963) 109 CLR 9, 20 (Menzies J (with whom Owen J agreed)).

${ }^{8}$ Belding v Read (1865) $3 \mathrm{H} \&$ C 995, 961 (Pollock CB).

${ }^{9}$ Warmstrey $v$ Tanfield (1628-29) 1 Ch Rep 29, 30; Bates v Dandy (1741) 3 Russ 89; 38 ER 505, 507 (Lord Hardwicke LC); Chauncy v Graydon (1743) 2 Atk 616, 621 (Lord Hardwicke LC); Grey $v$ Kentish (1749) 1 Atk 280, 280 (Lord Hardwicke LC); Alexander $v$ The Duke of Wellington (1831) 2 Russ \& My 35, 51 (Sir John Leach MR); Meek $v$ Kettlewell (1843) $1 \mathrm{Ph} \mathrm{342,} 347$ (Lord Lyndhurst LC); Roderick v Gandell (1849) 12 Beav 325, 330 (Lord Langdale MR); Lindsay v Gibbs (1856) 22 Beav 522, 528 (Sir John Romilly MR).
} 
conscience ${ }^{10}$ and overcome the equitable maxim, equity will not assist a volunteer. ${ }^{11}$

Apart from any statutory requirements of writing, an assignment of future property does not require any specific form. ${ }^{12}$ An equitable assignment 'may be couched in the language of command. It may be a courteous request. It may assume the form of mere permission. The language is immaterial if the meaning is plain. ${ }^{13}$ This stems from the equitable maxim, equity looks to substance rather than form. Having said this, an assignment of future property will not have occurred unless the assignor and assignee have agreed to the assignment. ${ }^{14}$

When legal title $\mathrm{e}^{15}$ to future property vests in the assignor, it will be held eo instanti on bare constructive trust for the assignee. ${ }^{16}$ As expressed by

${ }^{10}$ Chauncy v Graydon (1743) 2 Atk 616, 621 (Lord Hardwicke LC); Meek v Kettlewell (1843) $1 \mathrm{Ph}$ 342, 347 (Lord Lyndhurst LC); Bennett v Cooper (1845-1846) 9 Beav 252, 258 (Lord Langdale MR); Re Ellenborough, Towry Law v Burne [1903] 1 Ch 697, 700 (Buckley J); Redman v Permanent Trustee Co of NSW Ltd (1916) 22 CLR 84, 95-96 (Isaacs J); Palette Shoes Pty Ltd (in liquidation) v Krohn (1937) 58 CLR 1, 16 (Latham CJ); In Re Brooks' Settlement Trusts; Lloyds Bank Ltd v Tillard [1939] Ch 993, 998 (Farwell J); Norman v Federal Commissioner of Taxation (1963) 109 CLR 9, 21 (Menzies J (with whom Owen J agreed)), 24 (Windeyer J); Re Florio (1979) 97 DLR (3d) 74 [7] (MacKinnon J); Federal Commissioner of Taxation v Everett (1980) 143 CLR 440, 453 (Barwick CJ, Stephen, Mason and Wilson JJ); Re Androma Pty Ltd [1987] 2 Qd R 134, 138-39 (Connolly J), 149 (McPherson J); Westgold Resources NL v St George Bank Ltd (1998) 29 ACSR 396, 434 (Anderson J); Schipp v Cameron [1999] NSWSC 997 [863] (Einstein J); Porters $v$ Cessnock City Council [2005] NSWSC 1275 [25] (Campbell J); JT Nominees Pty Ltd v Macks (2007) 97 SASR 471 [116] \& [120] (Bleby J); Re Erskine 1948 Trust [2012] EWHC 732 (Ch) [46] (Mark Herbert QC).

${ }^{11}$ Williams v Commissioner of Inland Revenue [1965] NZLR 395, 399 (Turner J); Norman v Federal Commissioner of Taxation (1963) 109 CLR 9, 24 (Windeyer J).

12 William Brandt's Sons \& Co v Dunlop Rubber Co Ltd [1905] AC 454, 462 (Lord Macnaghten); Palette Shoes Pty Ltd (in liquidation) v Krohn (1937) 58 CLR 1, 15 (Latham CJ); Norman v Federal Commissioner of Taxation (1963) 109 CLR 9, 22 (Menzies J (with whom Owen J agreed)), 32 (Windeyer J); Shepherd $v$ Commissioner of Taxation (1965) 113 CLR 385, 391 (Barwick CJ); Elders Pastoral Ltd v Bank of New Zealand [1991] 1 NZLR 385, 387 (Lord Templeman); Tsu Soo Sin v Oei Tjiong Bin [2008] SGCA 46 [33] (Rajah JA).

13 William Brandt's Sons \& Co v Dunlop Rubber Co Ltd [1905] AC 454, 462 (Lord Macnaghten). See also Tailby $v$ Official Receiver (1888) 13 App Cas 523, 543 (Lord Macnaghten).

${ }^{14}$ Re Hamilton; FitzGeorge v FitzGeorge (1921) 124 LT 737, 739.

${ }^{15}$ It is also possible that an assignment of future property can occur with respect to equitable title (for example the beneficial interest of shares under a trust yet to be acquired by the assignor) but this is not typically encountered.

${ }^{16}$ Legard v Hodges (1792) 1 Ves Jun 478 (Lord Thurlow LC); In Re Gillott's Settlement; Chattock $v$ Reid [1934] 1 Ch 97, 108-09 (Maugham J); Bakewell v Deputy Federal Commissioner of Taxation (SA) (1937) 58 CLR 743, 761-62 (Starke J); Visbord v Federal Commissioner of Taxation (1943) 68 CLR 344, 383 (Williams J); Federal Commissioner of Taxation v Everett (1978) 21 ALR 625, 644 (Deane J); Federal Commissioner of Taxation v Everett (1980) 143 CLR 440, 450 (Barwick CJ, Stephen, Mason and Wilson JJ); Booth v Federal Commissioner of Taxation (1987) 164 CLR 159, 165 (Mason CJ), 178 (Toohey and Gaudron JJ); Hadlee v Commissioner of Inland Revenue [1991] 3 NZLR 517, 520 (Cooke P (with whom Casey and Hardie Boys JJ and Sir Gordon Bisson agreed)), 527 (Richardson J (with whom Casey and Hardie Boys JJ and Sir Gordon Bisson agreed)); Bluebottle UK Ltd v Deputy Commissioner of Taxation [2006] NSWSC 706 [60] (Gzell J); Deputy Commissioner of Taxation v Bluebottle UK Ltd [2006] NSWCA 360 [25]-[26] (Santow JA (with whom Mason P agreed)); RIL Aviation HL 7740 and HL 7741 Pty Ltd v 
McPherson $\mathrm{J}$ in Re Androma Pty Ltd $^{17}$ there is no 'scintilla temporis or fragment of time during which the equitable interest' vests in the assignor. ${ }^{18}$ The assignor will thus be required to transfer the legal title to the assignee forthwith. ${ }^{19}$

In a technical sense, equity does not assign future property immediately upon the making of a contract for valuable consideration to do so, as this would be a practical impossibility: one cannot immediately assign something that one does not have. ${ }^{20}$ Instead, equity 'activates' the formerly torpid agreement to assign once the legal title to the property is vested in the assignor as bare constructive trustee. ${ }^{21}$ This has been characterised as a special application of the equitable maxim: equity regards that as done which ought to be done. ${ }^{22}$

Finally, the assignee's right in equity to future property can be negated if the assignor sells the property to a bona fide purchaser for value without

Alliance \& Leicester plc [2011] NSWCA 423 [206]-[207] (Young JA); Commissioner of State Revenue v Abbotts Exploration Pty Ltd [2014] WASCA 211 [210] (Murphy JA); Lotteries Pty Ltd $v$ Volteas [2015] VSCA 226 [38] (Whelan JA (with whom Ferguson and McLeish JJA agreed)); Malcolm Cope, Constructive Trusts (Lawbook Company Limited, 1992) 999 (explaining that the trust is constructive).

${ }^{17}$ [1987] 2 Qd R 134.

${ }^{18}$ Ibid 135.

${ }^{19}$ It has been suggested that 'one way in which equity supports such an assignment is by treating the transaction, though in form an assignment, as containing or importing a covenant to do that which is necessary to effect the validity of the assignment.' See In re Mudge [1914] 1 Ch 115, 122 (Cozens-Hardy MR); Re Lind; Industrials Finance Syndicate Limited $v$ Lind [1915] 2 Ch 345, 370 (Bankes LJ).

${ }^{20}$ Collyer v Isaacs (1881) 19 Ch D 342, 351 (Jessel MR); Glegg v Bromley [1912] 3 KB 474, 490 (Parker J); Re Lind; Industrials Finance Syndicate Limited v Lind [1915] 2 Ch 345, 363 (Phillimore LJ); Horwood v Millar's Timber \& Trading Co Ltd [1917] 1 KB 305, 315 (Warrington LJ); Norman v Federal Commissioner of Taxation (1963) 109 CLR 9, 24-25 (Windeyer J); Re Androma Pty Ltd [1987] 2 Qd R 134, 138 (Connolly J); Watson v National Companies and Securities Commission [1988] WAR 332, 338-39 (Malcolm CJ (with whom Wallace and Brinsden JJ agreed)); Re Edelsten; Deputy Commissioner of Taxation (NSW) v Donnelly (1989) 89 ALR 232, 241 (von Doussa J); Ansett Australia Limited (subject to a deed of company arrangement) $v$ Travel Software Solutions Pty Ltd [2007] VSC 326 [51] (Hargrave J); FTV Holdings Cairns Pty Ltd v Smith [2014] QCA 217 [43] (Fraser JA (with whom Holmes JA and Ann Lyons J agreed)).

${ }^{21}$ Holroyd v Marshall (1862) 10 HLC 191; (1862) 11 ER 999, HLC 220; ER 1010 (Lord Chelmsford); Norman $v$ Federal Commissioner of Taxation (1963) 109 CLR 9, 24 (Windeyer J); Booth v Federal Commissioner of Taxation (1987) 164 CLR 159, 165 (Mason CJ); Deputy Commissioner of Taxation v Government Insurance Office of New South Wales (1993) 45 FCR 284; 117 ALR 61, 73 (Hill J (with whom Beazley J agreed)); Peter W Young, Clyde Croft and Megan Louise Smith, On Equity (Lawbook Co, 2009) 719.

${ }^{22}$ Palette Shoes Pty Ltd (in liquidation) v Krohn (1937) 58 CLR 1, 26 (Dixon J); Federal Commissioner of Taxation v Everett (1978) 21 ALR 625, 644 (Deane J); Booth v Federal Commissioner of Taxation (1987) 164 CLR 159, 178 (Toohey and Gaudron JJ); Hadlee v Commissioner of Inland Revenue [1991] 3 NZLR 517, 527 (Richardson J (with whom Casey and Hardie Boys JJ and Sir Gordon Bisson agreed)); McIntyre v Gye (1994) 122 ALR 289, 296-97 (Davies, Burchett and Gummow JJ); Lotteries Pty Ltd v Volteas [2015] VSCA 226 [38] (Whelan JA (with whom Ferguson and McLeish JJA agreed)); JD Heydon, MJ Leeming and PG Turner, Meagher, Gummow and Lehane's Equity Doctrines and Remedies (LexisNexis Butterworths, 5th ed, 2015) 269. 
notice of the earlier equitable assignment. ${ }^{23}$ Under these circumstances the earlier assignee will be entitled to damages from the assignor under breach of contract. ${ }^{24}$

\section{FUtURE PROPERTY AND LAND}

In Metcalfe $v$ Archbishop of York ${ }^{25}$ Lord Cottenham LC stated that: '[ $\left.\mathrm{t}\right]$ here can be no doubt that a covenant to charge or dispose of, or affect lands hereafter to be acquired, operates in equity upon lands so afterwards acquired.' ${ }^{26}$ Although at the abstract level it is certain that the doctrines of future property are applicable to land, in practice it is less certain exactly how this might occur. When analysing rules of future property vis-à-vis land, it is submitted that three initial issues require consideration: whether the land is future property; whether the assignment complies with any statutory requirements of writing; and how precisely the land must be described in order to make the assignment effective. Each are discussed seriatim below.

\section{A Is the Land Future Property?}

Land transactions usually involve present property. Typically, the assignor enters into a contract for the sale of land with the assignee, which is accompanied by the latter paying a ten per cent deposit. Six weeks ordinarily pass before settlement, whereupon the outstanding balance is paid by the assignee and the legal title is transferred. The key point which denotes that the agreement is one involving present property is that the assignor is the legal title holder at the time of making the contract with the assignee.

A land transaction can, however, involve future property. ${ }^{27}$ For example: the assignor assigns land which he or she does not yet have the legal title

${ }^{23}$ Holroyd v Marshall (1862) 10 HLC 191; (1862) 11 ER 999, HLC 219; ER 1010 (Lord Chelmsford); Joseph $v$ Lyons (1884) 15 QBD 280, 285 (Brett MR), 286 (Cotton LJ), 287 (Lindley LJ); Hallas $v$ Robinson (1885) 15 QBD 288, 291-92 (Brett MR), 292 (Baggallay LJ), 293 (Lindley LJ). See generally, Peter W Young, Clyde Croft and Megan Louise Smith, On Equity (Lawbook Co, 2009) 722.

${ }^{24}$ Government Employees Superannuation Board v Martin (1997) 19 WAR 224; BC9704036, 101 (Ipp J); Peter W Young, Clyde Croft and Megan Louise Smith, On Equity (Lawbook Co, 2009) 722 .

25 (1836) 1 My \& Cr 547; 40 ER 485.

${ }^{26}$ Ibid ER 489. See also Wilcocks $v$ Wilcocks (1706) 2 Ver 588; 23 ER 961; Morse v Faulkner (1792) 3 Swan 429; West v Berney (1819) 1 Rus \& My 431, 434 (Sir John Leach V-C); Imrie v Archibald (1895) 25 SCR 368, 387-88 (Sir Henry Strong CJC); Royal Bank v Madill (1981) 120 DLR (3d) 17 [73]-[79] (Stevenson J); Bridge Wholesale Acceptance Corporation (Aust) Ltd v Burnard (1992) 27 NSWLR 415, 421 (Clarke JA (with whom Mahoney and Meagher JJA agreed)).

${ }^{27}$ Wilcocks $v$ Wilcocks (1706) 2 Ver 588; 23 ER 961; Morse v Faulkner (1792) 3 Swan 429; West v Berney (1819) 1 Rus \& My 431, 434 (Sir John Leach V-C); Metcalfe v Archbishop of York (1836) 1 My \& Cr 547; 40 ER 485, 489 (Lord Cottenham LC). 
to, and may never obtain, to the assignee. ${ }^{28}$ The key point which denotes that the agreement is one involving future property is that the assignor is not vested with the legal title at the time of making the agreement with the assignee, and whether this will in fact ever occur is a mere contingency (beyond the assignor's control). Thus, whenever there is an element of chance involved with the assignor acquiring the legal title to land, an assignment of future property will have occurred.

\section{B Statutory Requirements of Writing}

A statutory requirement of writing ${ }^{29}$ applies to executory contracts for the sale of land. ${ }^{30}$ An assignment of future land is by its nature executory, as there are still further steps necessary in order to finalise, or execute, the intended disposition of the legal title. Writing is therefore required. ${ }^{31}$

It is often said, however, that the assignor of future property, once vested with the legal title, will be constituted as a bare constructive trustee for the assignee. ${ }^{32}$ Does this have any impact upon the foregoing? The answer is 'no'-even if the assignment is considered to create an executory trust in favour of the assignee, it is still required to be in writing under the same statutory provisions as a regular executory contract. ${ }^{33}$

\section{How Precisely the Land Must be Described In Order to Make the Assignment Effective}

Assuming that the previous two issues are satisfied, a third issue requires consideration, namely, how precisely the land must be described in order to make the assignment effective. The most usual and straightforward way that this will be satisfied is when land is described in specific detail, so as to enable identification in the future. If the assignor later becomes the legal

${ }^{28}$ A typical example might be the assignment of an expectancy of land under a will: Re Ellenborough, Towry Law v Burne [1903] 1 Ch 697, 699 (Buckley J); Bennett v Cooper (1845-1846) 9 Beav 252, 256-58 (Lord Langdale MR); Re Clarke; Coombe v Carter (1887) 36 Ch D 348, 352-53 (Cotton LJ), 357 (Bowen LJ), 358 (Fry LJ); Edwin M Hughs $\checkmark$ La Limited [2011] UKPC 9 [27] (Lord Walker (on behalf of the Privy Council)); Re Erskine 1948 Trust [2012] EWHC 732 (Ch) [46] (Mark Herbert QC).

${ }^{29}$ Section 54A(1) of the Conveyancing Act 1919 (NSW); s 126 of the Instruments Act 1958 (Vic); s 59 of the Property Law Act 1974 (Qld); s 26(1) of the Law of Property Act 1936 (SA); s 36(1) of the Conveyancing and Law of Property Act 1884 (Tas); s 201 of the Civil Law (Property) Act 2006 (ACT); s 62 of the Law of Property Act 2000 (NT). In Western Australia s 4 of the Statue of Frauds remains in effect although subject to the Law Reform (Statute of Frauds) Act 1962 (WA).

${ }^{30}$ The requirement of writing applies to old system title and Torrens title. See, for example, s 54A(3) of the Conveyancing Act 1919 (NSW).

${ }^{31}$ It is theoretically possible that the equitable doctrine of part performance might overcome any need for writing. See eg, s 54A(2) of the Conveyancing Act 1919 (NSW).

${ }^{32}$ See supra footnote 16.

${ }^{33}$ Khoury v Khouri [2006] NSWCA 184 [4]-[6] (Handley JA) [15] (Hodgson JA) [50]-[51] (Bryson JA). Once the land is vested in the assignor, the disposition to the assignee must also be in writing. See, for example, s 23C(1)(a) of the Conveyancing Act 1919 (NSW). 
owner of the land and refuses to honour the contract, the assignee will have recourse to equity to make good the transfer.

A more difficult question is whether a 'general' assignment of land will be valid. Take the following example: if the assignor agrees to assign any and all land in their possession to the assignee at a future point in time determinable by a particular condition, will the requirement of descriptive specificity be sufficiently met so as to make the assignment binding? In order to answer this question, it is necessary to consider the authorities on future assignments couched in general terms.

A requisite starting point is Holroyd $v$ Marshall. ${ }^{34}$ In that case Taylor, a damask manufacturer in Ovenden, York County, was in financial difficulties and sold machinery in his mill to AP and W Holroyd on terms which allowed Taylor to re-purchase for £5000. The machinery was transferred to Brunt, to hold it as trustee for Taylor absolutely if he should pay $£ 5000$ to AP and W Holroyd. The deed which set up this transaction included, 'all machinery, implements and things, which during the continuance of this security, shall be placed in or about' the mill. Taylor added further machinery to the mill without assuring it to the trustee, which his judgment creditors sought to levy execution against. AP and W Holroyd's title prevailed over that of Taylor's judgment creditors. Lord Westbury LC observed:

[I]f a vendor or mortgagor agrees to sell or mortgage property, real or personal, of which he is not possessed at the time, and he receives the consideration for the contract, and afterwards becomes possessed of property answering the description in the contract, there is no doubt that a Court of Equity would compel him to perform the contract, and that the contract would, in equity, transfer the beneficial interest to the mortgagee or purchaser immediately on the property being acquired. This, of course, assumes that the supposed contract is one of that class of which a Court of Equity would decree specific performance. ${ }^{35}$

The Lord Chancellor thus held that the assignment of future property would be ineffective, if, at the date when the future property enters the assignor's hands, the court would decline an order for specific performance of the contract to assign. This dictum subsequently caused difficulties for lower level courts which felt compelled to render assignments of future property ineffective if they were described in general, as opposed to specific, terms.

In Belding $v$ Read ${ }^{36}$ for example, the court was required to decide the degree of descriptive specificity necessary for the assignment of future property. The assignor, Randelstone, carried on a business as a grocer and draper, and had assigned to Read all his personal estate and effects, 'thereafter to be upon or about his dwelling house, farm and premises, situate in ... Reedham or elsewhere in Great Britain.' Read had seized and sold personalty acquired by the assignor after the execution of the deed,

34 (1862) 10 HLC 191; (1862) 11 ER 999.

${ }^{35}$ Ibid HLC 211; ER 1007.

${ }^{36}$ (1865) 3 H \& C 995. 
some of it having been taken from a dwelling house in Reedham, and some from another property in Great Yarmouth. The plaintiff, who was the trustee in bankruptcy of the assignor's estate, demanded an account of the property seized by Read. The court ultimately found that the assignment failed as it was cast too generally, lacking the requisite descriptive specificity. ${ }^{37}$ The court endorsed the position that an assignment of future property would only be binding if it was amenable to an order for specific performance. Martin B, for example, stated that, 'equitable title to goods as well as land is confined to specific goods, and does not extend to goods which are undetermined. ${ }^{38}$ Martin B continued that in Holroyd $v$ Marshall, ${ }^{39}$ "the property in dispute, which was new machinery, by being brought into the mill and affixed to the old machinery, was sufficiently earmarked to have entitled the mortgagee to file a bill for specific performance. ${ }^{40}$ Bramwell B also stressed the importance of descriptive specificity when assigning future property:

[In Holroyd $v$ Marshall] machinery, which in a sense was not specific when the deed was executed, having become specific by being brought into a particular mill, and made a part of its machinery, it was held that ... a covenant or grant of this nature would confer an equitable interest in it. ${ }^{41}$

Channell B similarly found that:

[I]n Holroyd $v$ Marshall ... the House of Lords appear only to have adopted and carried out that rule [what has been contracted to be done is to be considered done]. But the goods which formed the subject of that inquiry were goods of a specific character, brought upon the premises after the contract was made, and there affixed to and made part of the old machinery. ${ }^{42}$

The court thus attempted to maintain fidelity to Lord Westbury LC's dicta in Holroyd $v$ Marshall $^{43}$ by stressing the need for an assignment of future property to relate to specific, as opposed to general, property.

A similar method of reasoning was applied by Fry $\mathrm{J}$ in In re Count D'Epineuil (No 2). ${ }^{44}$ In that case the issue was whether a charge by the Count D'Épineuil 'of all my present and future personalty' in favour of the plaintiff, Tadman, was valid. Fry J, after considering Holroyd $v$ Marshall $^{45}$ and Belding $v$ Read, ${ }^{46}$ held that "equitable title to goods and land was confined to specific goods, and did not extend to goods which were

\footnotetext{
${ }^{37}$ An exception was the judgment of Pollock CB at 961-62 which failed to acknowledge that equity allows the assignment of future property for valuable consideration.

38 (1865) 3 H \& C 995, 962.

39 (1862) 10 HLC 191; (1862) 11 ER 999.

${ }^{40}$ (1865) 3 H \& C 995, 964.

${ }^{41}$ Ibid 964-65.

42 Ibid 965.

43 (1862) 10 HLC 191; (1862) 11 ER 999.

${ }^{44}$ (1882) 20 Ch D 758.

45 (1862) 10 HLC 191; (1862) 11 ER 999.

${ }^{46}$ (1865) 3 H \& C 995.
} 
undetermined.' 47 Furthermore, Fry J was concerned not to enforce the charge with respect to goods acquired after the date of the agreement on public policy grounds, as to do so would render the Count D'Épineuil destitute and unable to maintain himself. ${ }^{48}$

In Re Clarke; Coombe v Carter, ${ }^{49}$ the question of general and specific future property again emerged, this time in the context of an expectancy under a will. In that case the assignor, Hart, was a mortgagor, who had assigned to the mortgagee, South Essex Equitable Investments and Advances Company Limited, 'all moneys of or to which he then was or might during the security become entitled, under any settlement, will, or other document, either in his own right, or as a devisee, legatee, or next of kin of any person' and also all real and personal property 'of, in, or to which the mortgagor is or during this security shall become beneficially seised, possessed, entitled, or interested for any vested, contingent, or possible estate or interest.' Hart became entitled under the will of Clarke to a one twenty-third share of the residuary estate, and the testator's executor took out an originating summons to determine whether the share was included in Hart's mortgage. With reference to Clements $v$ Matthews, ${ }^{50}$ the court decided that the assignment was divisible into its constituent parts. ${ }^{51}$ This meant that aspects of the agreement which were general in nature were ineffective, and those aspects which were specific, namely, the assignment for valuable consideration of all moneys to which the assignor should become entitled under a will, were effective. Bowen LJ presciently noted the unsatisfactory nature of Holroyd $v$ Marshall ${ }^{52}$ and the need for appellate clarification in this branch of equitable jurisdiction:

The time will come when the Court of Appeal will have to consider the law as to assignments of future property, and to lay down, if it can, for the guidance of the profession some more definite rule than is to be gathered from the cases since Holroyd v. Marshall. As it seems to me, language has been used in some of them which tends to confuse the two distinct ideas, of vagueness in the contract, and vagueness which arises from the difficulty of identifying future property. 'Vagueness' is a misleading term. A contract may be so vague in its terms that it cannot be understood, and in that case it is of no effect at law or in equity. There is another kind of vagueness which arises from the property not being ascertained at the date of the contract, but if at the time when the contract is sought to be enforced the property has come in esse and is capable of being identified as that to which the contract refers, I cannot see why there is in it any such vagueness as to prevent a Court of Equity from enforcing the contract. ${ }^{53}$

\footnotetext{
47 (1882) 20 Ch D 758, 759-60.

48 Ibid 760. See, to similar effect, Re Clarke; Coombe v Carter (1887) 36 Ch D 348, 352 (Cotton LJ), 357-58 (Fry LJ); Horwood v Millar's Timber \& Trading Co Ltd [1917] 1 KB 305, 311 (Lord Cozens-Hardy MR); King v Michael Faraday and Partners Ltd [1939] 2 KB 753, 763-64 (Atkinson J).

${ }^{49}$ (1887) 36 Ch D 348.

50 (1882-83) LR 11 QBD 808.

${ }^{51}$ Re Clarke; Coombe v Carter (1887) 36 Ch D 348, 353-54 (Cotton LJ), 354-55 (Bowen LJ), 357-58 (Fry LJ).

52 (1862) 10 HLC 191; (1862) 11 ER 999.

53 (1887) 36 Ch D 348, 354-55.
} 
The question of specific and general future property reappeared in Official Receiver $v$ Tailby ${ }^{54}$ In that case a mortgagor, Izon, a Birmingham packing case manufacturer, assigned to a mortgagee, Tyrrell, inter alia, 'all the book debts due and owing or which may during the continuance of this security become due and owing to the said mortgagor.' Izon later supplied Wilson Brothers \& Co (WBC) with goods to the value of $£ 107 \mathrm{~s} 11 \mathrm{~d}$ on credit. Subsequent to this, Tyrell died, and his executors sought to call in the money due to his estate. The executors demanded payments, took possession of the mortgaged premises and sold the books debts. Shortly thereafter, Tailby, who had acquired the book debt relating to WBC, gave notice to the firm demanding payment, which was duly satisfied. Izon, meanwhile, had become bankrupt. The question was whether Tailby had a title to the book debt which was better than the official receiver in the administration of Izon's bankrupt estate.

At first instance, the county court judge, relying on the authorities of Belding $v$ Read $^{55}$ and In re Count D'Epineuil (No 2), ${ }^{56}$ held that Izon's assignment of future book debts to Tyrrell was ineffective, as it lacked the requisite descriptive specificity. On appeal, Matthew and Hawkins JJ reversed this result, ${ }^{57}$ noting that if unspecified future stock in trade might be assigned, as indicated by Clements $v$ Matthews, ${ }^{58}$ then so too might unspecified future book debts, despite authority to the contrary in Belding $v$ Read $^{59}$ and In re Count D'Epineuil (No 2). ${ }^{60}$ On further appeal, this result was reversed, with Lord Esher MR holding that the assignment of the future books debts was 'too vague', but if the assignment of the book debts had been confined to 'future book debts accruing due in a particular business' this would not be the case. ${ }^{61}$ Lindley LJ took a similar view, explicitly linking the assignment of future property with specific performance:

The question, therefore, in such a case as this must, as it seems to me, be determined with reference to the doctrine of specific performance. I think that it would be going far beyond any of the cases that have been decided to say that specific performance would be decreed of such a contract as this. I do not say that an assignment of future book debts must necessarily be too vague; but, where there is no limitation of them with regard to any particular business, I think the assignment is too vague. ${ }^{62}$

\footnotetext{
${ }^{54}(1888) 18$ QBD 25.

55 (1865) 3 H \& C 995.

56 (1882) 20 Ch D 758.

57 (1886) 17 QBD 88, 92-93 (Mathew and Hawkins JJ).

58 (1883) 11 QBD 808.

59 (1865) 3 H \& C 995.

${ }^{60}$ (1882) 20 Ch D 758.

${ }^{61}$ (1888) 18 QBD 25, 29.

${ }^{62}$ Ibid 30-31.
} 
Lopes LJ, relying on Holroyd $v$ Marshall ${ }^{63}$ and Belding $v$ Read, ${ }^{64}$ likewise stressed the need for an assignment of future property to be specific as opposed to general. ${ }^{65}$

The result was appealed to the House of Lords in Tailby $v$ Official Receiver. ${ }^{66}$ Lord Herschell expounded:

Now whatever the learned Lord [Westbury LC] meant [in Holroyd $v$ Marshall] by limiting the doctrine to the class of cases in which a Court of Equity would decree specific performance, he certainly did not intend to exclude cases in which after-acquired property fell within general descriptive words contained in the deed, for he enforced the security in that very case against such property. Nor, again, can I find any trace of the view that a Court of Equity would not enforce a contract relating to future-acquired property if it was vague, in the sense of embracing much within its terms, for, as I have pointed out, Courts of Equity have frequently enforced such contracts. ${ }^{67}$

Lord Watson similarly noted:

Mere difficulty in ascertaining all the things which are included in a general assignment, whether in esse or in posse, will not affect the assignee's right to those things which are capable of ascertainment or are identified. ${ }^{68}$

Lord Macnaghten explicitly clarified the relationship between the assignment of future property, the need for descriptive specificity and specific performance:

Greater confusion still, I think, would be caused by transferring considerations applicable to suits for specific performance ... to cases of equitable assignment or specific lien. ... The doctrines relating to specific performance do not, I think, afford a test or measure of the rights accrued. ${ }^{69}$

The House of Lords thus removed the tendency in cases such as Belding $v$ Read,$^{70}$ In re Count D'Epineuil (No 2), ${ }^{71}$ Re Clarke; Coombe $v$ Carter, ${ }^{72}$ and Official Receiver $v$ Tailby ${ }^{73}$ to make general assignments of future property ineffective.

\footnotetext{
${ }^{63}$ (1862) 10 HLC 191; (1862) 11 ER 999.

${ }^{64}$ (1865) 3 H \& C 995.

${ }^{65}$ (1888) 18 QBD 25, 31.

${ }^{66}(1888) 13$ App Cas 523.

${ }^{67}$ Ibid 531.

${ }^{68}$ Ibid 533.

${ }^{69}$ Ibid 547-48. This view was adopted, even though all of their Lordships in Tailby $v$ Official Receiver (1888) 13 App Cas 523 felt the result in Belding v Read (1865) 3 H \& C 995 was, with respect to the facts therein, decided incorrectly. See JF Keeler, 'Some Reflections on Holroyd v. Marshall' (1967-70) 3 Adelaide Law Review 369.

${ }^{70}$ (1865) 3 H \& C 995.

${ }^{71}(1882) 20$ Ch D 758.

${ }^{72}$ (1887) 36 Ch D 348.

73 (1888) 18 QBD 25.
} 
This overall interpretation was subsequently confirmed by the widespread recognition of floating charges in the late nineteenth century. ${ }^{74}$ This is because the very nature of a floating charge allows the chargor to charge all present and future property which might circulate through the business. A floating charge (or in contemporary parlances, a circulating security interest $)^{75}$ thus comprises a general assignment of future property. ${ }^{76}$ Indeed it was this exact type of interest that the House of Lords was grappling with in Holroyd $v$ Marshall, ${ }^{77}$ although a suitable descriptor had not yet been devised.

Beyond the company floating charge context, that an assignment of future land might be couched in general terms has been explicitly approved in Bridge Wholesale Acceptance Corporation (Aust) Ltd v Burnard. ${ }^{78}$ In that case Burnard and Florence, trading as Burnard and Sons, had entered into a leasing agreement with Bridge Wholesale Corporation Australia Ltd (BWCAL) for forklift trucks and accessories for a period of forty-two months. On the same day, Burnard and Florence entered into a deed with BWCAL, which guaranteed payment of all money due under the lease. The deed allowed BWCAL, upon payment default, to place a legal mortgage over 'any land now or hereafter held' by Burnard and Florence. Default occurred and BWCAL lodged a caveat over Torrens land owned by Burnard claiming a right to a grant of a legal or equitable mortgage in respect of all outstanding moneys secured by the deed. On examining the reference to present and future land in the deed, Clarke JA stated:

[I]n Belding v Read (1865) 3 H \& C 995; 159 ER 812, that an assignment by way of mortgage of all the mortgagors' personal estate and effects thereafter to be upon or about his dwelling-house, farm and premises situate at Reedham ... or elsewhere in Great Britain failed both at law and at equity. This decision was followed in Re Count D'Epineuil (1882) 20 Ch D 758. In that case Fry J proceeded on the basis, which he drew from the judgment of Baron Martin in Belding, that the equitable title to goods as well as to land was confined to specific goods, and did not extend to goods which were

${ }^{74}$ See, eg, Re Panama, New Zealand and Australian Royal Mail Co (1870) 5 Ch App 318, 322 (Giffard LJ); Re Florence Land and Public Works Co, ex parte Moor (1878) 10 Ch D 530, 541-43 (Jessel MR), 546-47 (James LJ), 549-50 (Thesiger LJ); Re Colonial Trusts Corporation, ex parte Bradshaw (1879) 15 Ch D 465, 472 (Jessel MR) (using the expression 'floating security'). The expression 'floating charge' seems to have been coined by Lord Macnaghten in Governments Stock and Other Securities Investment Co Ltd v Manila Railway Co [1897] AC 81, 86; Another early use of the expression can be traced to Romer LJ in Illingworth $v$ Houldsworth [1904] AC 355, 295. See generally Agnew and Kevin James Bearsley v The Commissioner of Inland Revenue and Official Assignee for the estate in bankruptcy of Bruce William Birtwhistle and Mark Leslie Birtwhistle [2001] 2 AC 710 [5] (Lord Millet (on behalf of the Privy Council)); National Westminster Bank plc v Spectrum Plus Limited [2005] UKHL 41 [95]-[97] (Lord Scott of Foscote).

${ }^{75}$ See s 51C of the Corporations Act 2001 (Cth); Re CMI Industrial Pty Ltd (In Liq); Byrnes v CMI Limited [2015] QSC 96 [7] (Mullins J); Hamersley Iron Pty Ltd v Forge Group Power Pty Ltd (in liquidation) (receivers and managers appointed) [2017] WASC 152 [125] (Tottle J); Langdon, in the matter of Forge Group Limited (Receivers and Managers Appointed) (in Liq) [2017] FCA 170 [59] (Gilmour J).

${ }^{76}$ Robert Pennington 'The Genesis of the Floating Charge' (1960) 23 Modern Law Review 634-38.

77 (1862) 10 HLC 191; (1862) 11 ER 999.

78 (1992) 27 NSWLR 415. 
undetermined (at 760). Both these cases were over-ruled in Tailby $v$ Official Receiver (1888) 13 App Cas 523 and have since been regarded as having been based on a misunderstanding of Holroyd. ${ }^{79}$

His Honour thus affirmed that general assignments of future property would be effective. ${ }^{80}$ Interestingly, Clarke JA was disinclined to the view that an assignment of future property couched in general terms might not be effective on the grounds of public policy, as intimated by Fry $\mathrm{J}$ in In re Count D'Epineuil (No 2). ${ }^{81}$ Rather, Clarke JA felt that existing protections with respect to hardship and unfairness would be adequate, although ultimately he noted that he did not need to reach a firm conclusion on the matter. ${ }^{82}$

Before concluding the present section it is incumbent to observe that the current state of the law with respect to descriptive specificity and the assignment of future property represents a return to the position which preceded Holroyd $v$ Marshall. ${ }^{83}$ In Bennett $v$ Cooper ${ }^{84}$ for example, Lord Langdale MR upheld an assignment 'if necessary, to sue for and receive, all sums of money then or thereafter to become due ... and all legacies or bequests, which had already or might thereafter be given or bequeathed ... by any person whomsoever.' Indeed two of the Law Lords in Tailby $v$ Official Receiver ${ }^{85}$ were at pains to refer to this case. ${ }^{86}$

It emerges from the foregoing that there are no barriers to a general assignment of future land. Nor are there any barriers to a general assignment of future land and personalty. Thus, any suggestion that descriptive specificity is necessary in order to make an assignment of future land effective cannot be sustained. Having said this, it must still be possible to determine that there was an intention that the land in question would be included within the assignment's ambit at the time of the agreement. ${ }^{87}$ In the final analysis, the validity of a general assignment of land will thus turn upon interpretation of the wording employed.

\footnotetext{
${ }^{79}$ Ibid 422 (Clarke JA (with whom Mahoney and Meagher JA agreed)).

${ }^{80}$ See also Chief Commissioner of State Revenue v Platinum Investment Management Ltd [2011] NSWCA 48 [14] (Campbell JA).

81 (1882) 20 Ch D 758, 760 (Fry J). See also Re Clarke; Coombe v Carter (1887) 36 Ch D 348, 352 (Cotton LJ), 357-358 (Fry LJ); Horwood v Millar's Timber \& Trading Co Ltd [1917] 1 KB 305, 311 (Lord Cozens-Hardy MR); King v Michael Faraday and Partners Ltd [1939] 2 KB 753, 763-64 (Atkinson J).

82 (1992) 27 NSWLR 415, 423 (Clarke JA (with whom Mahoney and Meagher JA agreed)). It should be noted that a floating charge cannot now be granted by a natural person: $\mathrm{s} 45$ of the National Credit Code (found in Schedule 1 of the National Consumer Credit Protection Act 2009 (Cth)).

83 (1862) 10 HLC 191; (1862) 11 ER 999.

${ }^{84}(1845-1846) 9$ Beav 252.

85 (1888) 13 App Cas 523.

${ }^{86}$ Ibid 530 (Lord Herschell), 535 (Lord Watson).

${ }^{87}$ See, for example, Re Kelcey; Tyson v Kelcey [1899] 2 Ch 530, 533 (Kekewich J); Re Carter

Holt Harvey Woodproducts (Australia) Pty Ltd (No 1) [2017] VSC 499 [44] (Robson J).
} 


\section{FUTURE PROPERTY AND TORRENS LAND}

The relationship between equity and the Torrens system in the late nineteenth century was strained. This no doubt stemmed from the two paramount goals of the Torrens system: (1) to create a less complex land title system thereby reducing transaction costs; and (2) to provide title certainty in a colonial outpost with a dearth of legal skills necessary to properly administer common law title. ${ }^{88}$ Robert Richard Torrens ${ }^{89}$ pursued these two goals by instituting a land title system inspired by merchant shipping legislation which forbade the creation of equitable interests in ships. Early Torrens cases, such as Lange $v$ Ruwoldt ${ }^{90}$ echoed these influences, holding that equitable interests stood outside the Torrens statutory regime. ${ }^{91}$ Over time, however, this view was rejected, ${ }^{92}$ finally being laid definitively to rest in Barry $v$ Heider ${ }^{93}$ Although today it could be scarcely denied that equitable interests are subsumable within the Torrens system, it is less certain precisely how principles of future property would apply to Torrens land. ${ }^{94}$ Take the following example: $\mathrm{X}$ has an expectancy under Z's will to inherit Torrens land and makes an assignment of this expectancy to $\mathrm{Y}$ for valuable consideration. What are the legal implications? It is submitted that three issues beckon analysis: the nature of the interest created; the potential operation of the law of caveats; and the potential operation of the in personam exception to indefeasibility in the event that the assignor refuses to honour the contract. Each are discussed seriatim below.

\section{A The Nature of the Interest Created}

The Torrens system is one of "title by registration' 95 meaning that the rights of the registered proprietor flow from the 'the act of registration and not

${ }^{88}$ P Moerlin Fox, 'The Story Behind the Torrens System' (1950) 23 Australian Law Journal 489; Rosalind Atherton, '150 Years of Torrens-Too Much, Too Little, Too Soon, Too Late?', Forbes Lecture, 6 November 2008, 2; Peter Butt, Land Law (Lawbook Co, 6th ed, 2010) 745 .

${ }^{89}$ For the contributions of Torrens generally, see Greg Taylor, 'The Emergence of the Torrens System' in Hossein Esmaeili and Brendan Grigg (eds) The Boundaries of Australian Property Law (Cambridge, 2016) 28-30. It has also been suggested that a South Australian lawyer, Dr Ulrich Hübbe (German born living in Adelaide), was an influential figure in the Torrens system's development. See Horst K. Lücke, 'Ulrich Hübbe and the Torrens System' (2009) 30(2) Adelaide Law Review 213-44; Murray Raff, 'Torrens, Hübbe, Stewardship and the Globalisation of Property Law Systems' (2009) 30(2) Adelaide Law Review 245-90; See also Creque v Penn [2007] UKPC 44 [13] (Lord Walker of Gestingthorpe (on behalf of the Privy Council)).

90 (1872) 7 SALR 1.

${ }^{91}$ Ibid 7-9 (Hanson CJ), 13-17 (Gwynne J), 18 (Wearing J).

92 Cutherbertson v Swan (1877) 11 SALR 102, 106-100 (Stow J (with whom Way CJ agreed)).

${ }^{93}$ (1914) 19 CLR 197, 206-07 (Griffith CJ (with whom Barton J agreed)), 216 (Isaacs J).

${ }^{94}$ See generally, with respect to future property and Torrens land, Bridge Wholesale Acceptance Corporation (Aust) Ltd v Burnard (1992) 27 NSWLR 415.

${ }^{95}$ Breskvar v Wall (1971) 126 CLR 376, 385 (Barwick CJ (with whom Owen J agreed)); See also Gazzo v Comptroller of Stamps (Vict) (1981) 149 CLR 227, 274 (Aicken J); Leros Pty Ltd v Terara Pty Ltd (1992) 174 CLR 407, 418 (Mason CJ, Dawson and McHugh JJ); 
from an event antecedent thereto.' ${ }^{96}$ Would then the assignee's interest be capable of registration? The answer is 'no'. Two principal reasons can be advanced to justify this view. First, prior to the assignor taking the registered title, the nature of the assignee's right is highly contingent and to speak of registration in such a context would be nonsensical; how can one register an interest which may never eventuate? Second, even if the assignor becomes the registered proprietor, the assignee's interest remains equitable, akin to that of a beneficiary under a bare constructive trust, and is thus unable to be registered under the Torrens system. ${ }^{97}$ This means that the interest of an assignee under a contract for sale of future Torrens land would be an unregistrable interest.

Parramore v Duggan (1995) 183 CLR 633, 635 (Brennan J); Allders International Pty Ltd $v$ Commissioner of State Revenue in his capacity as Comptroller of Stamps (1996) 186 CLR 630, 661 (Toohey J); Forestview Nominees Pty Ltd v Perpetual Trustees WA Ltd (1998) 193 CLR 154, 160 (Gaudron, McHugh, Gummow, Kirby and Hayne JJ); Figgins Holdings Pty Ltd v SEAA Enterprises Pty Ltd (1999) 196 CLR 245, 262 (Gaudron, Gummow and Callinan JJ); Hillpalm Pty Ltd v Heaven's Door Pty Ltd (2004) 220 CLR 472, 490 (McHugh ACJ, Hayne and Heydon JJ) 503 (Kirby J); Halloran v Minister Administering National Parks and Wildlife Act 1974 (2006) 229 CLR 545, 559-60 (Gleeson CJ, Gummow, Kirby and Hayne JJ); Black v Garnock (2007) 230 CLR 438, 443 (Gummow and Hayne JJ); Westfield Management Ltd v Perpetual Trustee Co Ltd (2007) 233 CLR 528, 531, 539 (Gleeson CJ, Gummow, Kirby, Hayne and Heydon JJ); Koompahtoo Local Aboriginal Land Council v KLALC Property Investment Pty Ltd [2008] NSWCA 6 [28] (Giles J (with whom Tobias JA agreed)) [130] (Young CJ in Eq); Perpetual Trustees Victoria Limited v English [2010] NSWCA 32 [7] (Sackville AJA (with whom Allsop P and Campbell JA agreed)); Perpetual Trustee Co Ltd v Smith [2010] FCAFC 91 [54] (Moore and Stone JJ); Ermora Pty Ltd v Kelvedon Pty Ltd [2011] WASC 281 [37] (Edelman J); Sahab Holdings Pty Ltd v Registrar-General (No 2) [2012] NSWCA 42 [23] (Campbell JA and Tobias AJA); Salia Property Pty Ltd v Commissioner of Highways [2012] SASCFC 33 [55] (Doyle CJ (with whom Anderson and Stanley JJ agreed)); Gerard Cassegrain \& Co Pty Limited v Felicity Cassegrain [2013] NSWCA 453 [12] (Beazley P (with whom Macfarlan JA agreed)); Castle Constructions Pty Limited v Sahab Holdings Pty Ltd (2013) 247 CLR 149, 159 (Hayne, Crennan, Kiefel and Bell JJ); Mekpine Pty Ltd v Moreton Bay Regional Council [2014] QCA 317 [82] (Morrison JA); Cassegrain v Gerard Cassegrain \& Co Pty Ltd (2015) 254 CLR 425, 433, 442 (French CJ, Hayne, Bell and Gageler JJ), 455 (Keane J); Registrar-General of New South Wales $v$ Jea Holdings (Aust) Pty Ltd [2015] NSWCA 74 [106] (Bathurst CJ and Beazley P); Anderson v Anderson [2017] NSWCA 131 [53] (Leeming JA (with whom Basten JA and Sackville AJA agreed)).

${ }^{96}$ Mayer v Coe [1968] 2 NSWR 747, 754 (Street J); Farah Constructions Pty Ltd v Say-Dee Pty Ltd (2007) 230 CLR 89, 170 (Gleeson CJ, Gummow, Callinan, Heydon and Crennan JJ); St Vincent de Paul Society Qld v Ozcare Ltd [2009] QCA 335 [76] (Muir JA (with whom McMurdo P and Chesterman JA agreed)); Gerard Cassegrain \& Co Pty Limited v Felicity Cassegrain [2013] NSWCA 453 [12] (Beazley P (with whom Macfarlan JA agreed)); Sze Tu v Lowe [2014] NSWCA 462 [240] (Gleeson JA (with whom Meagher and Barrett JJA agreed)).

${ }^{96}$ Whatever doubt there may have been concerning the recognition of equitable interests in the Torrens context was dispelled by Barry v Heider (1914) 19 CLR 197, 206-07 (Griffith CJ), 216 (Isaacs J). See also Abigail v Lapin [1934] AC 491; (1934) 51 CLR 58, 64 (Lord Wright (on behalf of the Privy Council)).

${ }^{97}$ Torrens legislation prescribes that where a trust deed exists, it cannot be registered: s 82 of the Real Property Act 1900 (NSW); s 37 of the Transfer of Land Act 1958 (Vic); s 162 of the Real Property Act 1886 (SA); s 155 of the Transfer of Land Act 1893 (WA); s 132 of the Land Titles Act 1980 (Tas); s 124 of the Land Titles Act 1925 (ACT). The situation may be slightly different under s 132(3) of the Land Titles Act 1980 (Tas), where the recorder may describe the registered proprietor as a trustee; See also Abigail v Lapin [1934] AC 491; (1934) 51 CLR 58, 65 (Lord Wright (on behalf of the Privy Council)); In re Peychers' Caveat [1954] NZLR 285, 286 (Archer J). 


\section{The Exact Nature of the Assignee's Interest Prior to the Assignor Becoming the Registered Proprietor}

It is interesting to consider the exact nature of the assignee's interest prior to the assignor becoming the registered proprietor. Clearly, it is contingent and thus unlike a regular equitable interest. This is reflected in the fact that an assignment of future property is said to only take effect once the legal title to the property vests in the assignor as bare constructive trustee. ${ }^{98}$

Does this mean that prior to the registered title vesting in the assignor, there is simply no equitable interest in favour of the assignee? This position, it would seem, is going too far. The contractual agreement to assign is, after all, created prior to the registered title vesting in the assignor. Moreover, various cases involving future property outside of the Torrens system have suggested that the assignee's equitable interest can transcend the assignor's bankruptcy. ${ }^{99}$ Correspondingly, the assignee's right has been characterised as 'higher' than mere contract. ${ }^{100}$ If this is the established law, it indicates that there must be an equitable interest, albeit nascent, torpid and nonproprietary, in favour of the assignee prior to the registered title vesting in the assignor. ${ }^{101}$

${ }^{98}$ Holroyd v Marshall (1862) 10 HLC 191; (1862) 11 ER 999, HLC 220; ER 1010 (Lord Chelmsford); Norman v Federal Commissioner of Taxation (1963) 109 CLR 9, 24 (Windeyer J); Booth v Federal Commissioner of Taxation (1987) 164 CLR 159, 165 (Mason CJ); Deputy Commissioner of Taxation v Government Insurance Office of New South Wales (1993) 45 FCR 284; 117 ALR 61, 73 (Hill J (with whom Beazley J agreed)); Peter W Young, Clyde Croft and Megan Louise Smith, On Equity (Lawbook Co, 2009) 719.

${ }^{99}$ Re Lind; Industrials Finance Syndicate Limited v Lind [1915] 2 Ch 345, 373-74 (Bankes LJ), 360 (Swinfen Eady LJ), 356-66 (Phillimore LJ); Palette Shoes Pty Ltd (in liquidation) $v$ Krohn (1937) 58 CLR 1, 26-27 (Dixon J); Akron Tyre Co Pty Ltd v Kittson (1951) 82 CLR 477, 485 (Latham CJ), 493 (Kitto and Williams JJ); Norman v Federal Commissioner of Taxation (1963) 109 CLR 9, 24 (Windeyer J); Re Florio (1979) 97 DLR (3d) 74 [7][10] (MacKinnon J); Booth v Federal Commissioner of Taxation (1987) 164 CLR 159, 165 (Mason CJ), 178 (Toohey and Gaudron JJ); Re Puntoriero; Ex parte Nickpack Pty Ltd (1991) 104 ALR 523, 531 (Einfeld J); Deputy Commissioner of Taxation v Government Insurance Office of New South Wales (1993) 45 FCR 284; (1993) 117 ALR 61, 63-64 (Jenkinson J), 73-74 (Hill J (with whom Beazley J agreed)); JT Nominees Pty Ltd v Macks (2007) 97 SASR 471 [118]-[121] (Bleby J); See JD Heydon, MJ Leeming and PG Turner, Meagher, Gummow and Lehane's Equity Doctrines and Remedies (LexisNexis Butterworths, 5th ed, 2015) 268-69; Peter W Young, Clyde Croft and Megan Louise Smith, On Equity (Lawbook Co, 2009) 721.

${ }^{100}$ Re Lind; Industrials Finance Syndicate Limited v Lind [1915] 2 Ch 345, 356-66 (Phillimore LJ). See also ibid, 373-74 (Bankes LJ), 360 (Swinfen Eady LJ); Palette Shoes Pty Ltd (in liquidation) v Krohn (1937) 58 CLR 1, 27 (Dixon J); Booth v Federal Commissioner of Taxation (1987) 164 CLR 159, 165 (Mason CJ); Peer International Corpn v Termidor Music Publishers Ltd (Editora Musical de Cuba, Part 20 Defendant) [2004] RPC 431 [76] (Neuberger J); FTV Holdings Cairns Pty Ltd v Smith [2014] QCA 217 [44] (Fraser JA (with whom Holmes JA and Ann Lyons J agreed)); JT Nominees Pty Ltd v Macks (2007) 97 SASR 471 [119] (Bleby J); Lotteries Pty Ltd v Volteas [2015] VSCA 226 [35] (Whelan JA (with whom Ferguson and McLeish JJA agreed)).

${ }^{101}$ It has been observed that ' $[\mathrm{e}] \mathrm{ven}$ before the property in question comes into existence under this equitable doctrine ... the assignee's prospective rights are "more than equitable rights in personam." See Commissioner of State Revenue v Abbotts Exploration Pty Ltd [2014] WASCA 211 [210] (Murphy JA). 
Is then the assignee's equitable interest a mere equity? The answer is 'no'. A mere equity is generally considered to connote an equitable interest which requires the assistance of a court of equity in order to be perfected - an equitable mortgage established by the doctrine of part performance prior to a court of equity's validation is a good example. ${ }^{102}$ The interest of an assignee of future land does not comport with this category of interest, as prior to the registered title vesting in the assignor, there is simply no existing proprietary interest which a court of equity can perfect.

This leads to the conclusion that prior to the registered title vesting in the assignor, there is a sui generis contingent equitable interest. ${ }^{103}$ The hallmarks of this interest are nascence, torpidity, and non-proprietariness. ${ }^{104}$ This interest may convert to a regular equitable interest endowed with a proprietary character if the registered title subsequently vests in the assignor. This conversion has been explained as an exceptional application of the equitable maxim, equity regards that as done which ought to be done. ${ }^{105}$

\section{B The Law of Caveats}

It is uncontroversial that in the case of a regular contract for the sale of land the assignee has, prior to settlement, an equitable interest in the property which is capable of protection by caveat. ${ }^{106}$ The question at the present juncture is whether a caveat could be lodged by the assignee of future Torrens land. No guidance exists in the case law on this issue. As indicated by Torrens legislation, however, a caveat can be lodged by any person in relation to an unregistered dealing who claims to be entitled to a legal or

102 Double Bay Newspapers Pty Ltd v AW Holdings Pty Ltd (1996) 42 NSWLR 409, 425 (Bryson J); Mills v Ruthol Pty Ltd [2002] NSWSC 294 [131] (Palmer J); Westpac Banking Corporation v Ollis [2008] NSWSC 824 [73]-[75] (Einstein J). See also general discussion, Garwoli v Garwoli [2015] SASC 1 [14]-[15] (Dart J).

${ }^{103}$ Heydon, Leeming and Turner suggest that the exact nature of the interest in the assignee before the legal title is vested in the assignor 'remains unresolved.' The same scholars thereafter posit that the interest is 'abstract' and 'sui generis'. JD Heydon, MJ Leeming and PG Turner, Meagher, Gummow and Lehane's Equity Doctrines and Remedies (LexisNexis Butterworths, 5th ed, 2015) 269.

${ }^{104}$ Heydon, Leeming and Turner have stated, '[w] hat is the exact nature of the assignee's rights before the property comes into existence? Authority establishes that it is more than a right of contract. But it cannot at that stage be an interest in property because there is no property in existence, or in the hands of the assignor, to which it can attach.' JD Heydon, MJ Leeming and PG Turner, Meagher, Gummow and Lehane's Equity Doctrines and Remedies (LexisNexis Butterworths, 5th ed, 2015) 269.

105 Ibid; See also Palette Shoes Pty Ltd (in liquidation) v Krohn (1937) 58 CLR 1, 26 (Dixon J); Federal Commissioner of Taxation v Everett (1978) 21 ALR 625, 644 (Deane J); Booth $v$ Federal Commissioner of Taxation (1987) 164 CLR 159, 178 (Toohey and Gaudron JJ); Hadlee v Commissioner of Inland Revenue [1991] 3 NZLR 517, 527 (Richardson J (with whom Casey and Hardie Boys JJ and Sir Gordon Bisson agreed)); McIntyre v Gye (1994) 122 ALR 289, 296-97 (Davies, Burchett and Gummow JJ); Lotteries Pty Ltd v Volteas [2015] VSCA 226 [38] (Whelan JA (with whom Ferguson and McLeish JJA agreed)).

106 See for example, Re Scanlan (1887) 3 QLJ 43; Woodberry v Gilbert (1907) 3 Tas LR 7, 9 (Clark J); Hill v Keene (1903) 23 NZLR 404, 405 (Stout CJ); Wheeler v Baldwin (1934) 52 CLR 609, 630 (Dixon J); Fernandes v Houstein (1963) 4 FLR 355, 357-58 (Dunphy J); Galvasteel Pty Ltd v Monterey Building Pty Ltd (1974) 10 SASR 176, 180-81 (Walters J). 
equitable estate or interest in land. ${ }^{107}$ The question must be then: is the interest of an assignee of future Torrens land an equitable estate or interest in that land?

Prior to the assignor becoming the registered proprietor, the answer is 'no', as the equitable right which the assignee has is non-proprietary; it is, as noted above, a sui generis contingent equitable interest. An example may serve to better illustrate the conclusion. Assume that $\mathrm{X}$ has an expectancy under Z's will of Torrens land and agrees to make an assignment of that land to $\mathrm{Y}$ for valuable consideration. In these circumstances, it would be improper to allow $\mathrm{Y}$ to place a caveat upon Z's title. ${ }^{108} \mathrm{Z}$ is entirely removed from the contract concerning $\mathrm{X}$ and $\mathrm{Y}$ which is contingent. It is possible, for example, that $\mathrm{Z}$ may decide at any time to sell the property or may will the property elsewhere. ${ }^{109}$

The result, however, is different once the assignor takes the registered title. This is because the element of contingency is eliminated, and the contractual obligations which exist between the assignor and assignee can be given proper effect; the sui generis contingent equitable interest is converted to a regular equitable interest. At this point, the assignee is able to lodge a caveat to protect their equitable interest in the land, having a stable proprietary interest. Interestingly, the lodging of a caveat in these circumstances has two currently recognised analogues: the interest of a purchaser under an executory contract for the sale of land, ${ }^{110}$ or alternatively, the interest of a beneficiary under a bare trust requiring transfer. ${ }^{111}$

${ }^{107}$ Section 74F(1) of the Real Property Act 1900 (NSW); s 89(1) of the Transfer of Land Act 1958 (Vic); ss 122, 124 of the Land Title Act 1994 (Qld); s 191 of the Real Property Act 1886 (SA); s 137 of the Transfer of Land Act 1893 (WA); s 133 of the Land Titles Act 1980 (Tas); s 104 of the Land Titles Act 1925 (ACT); ss 138, 140 of the Land Title Act (NT); For discussion of s 74F(1) of the Real Property Act 1900 (NSW) see Taleb v National Australia Bank Ltd [2011] NSWSC 1562 [40] (Bryson JA).

108 This draws support from dicta in other contexts which have suggested that a caveatable interest must exist at the time the caveat is lodged - it cannot be lodged to protect a future interest: Martin v Official Trustee in Bankruptcy [1990] Tas R 65, 69 (Green CJ); Gangemi v Gangemi [2009] WASC 195 [40] (Murphy J); Stacey v Stacey [2010] WASC 85 [12] (Beech J); Westpac Banking Corporation v Murray Riverside Pty Ltd [2013] WASC 433 [20] (Beech J) Watson v Gardner [2015] WASC 192 [14] (Mitchell J); Binning (as administratrix of the estate of Cowan) v Avsar [2016] WASC 194 [120] (Kenneth Martin J).

${ }^{109}$ In re Parsons; Stockley v Parsons (1890) 45 Ch D 51, 55 (Kay J); Ogden Industries Pty Limited $v$ Lucas (1968) 118 CLR 32, 37 (Lord Upjohn (on behalf of the Privy Council)); Klewer v Official Trustee in Bankruptcy (No 2) [2008] FCA 1788 [50] (Bennett J); George $v$ Fletcher (Trustee) [2010] FCAFC 53 [106] (Marshall J); Frigger $v$ Reid [2017] WASC 138 [11] (Martino J).

${ }^{110}$ Re Scanlan (1887) 3 QLJ 43; Woodberry v Gilbert (1907) 3 Tas LR 7, 9 (Clark J); Hill v Keene (1903) 23 NZLR 404, 405 (Stout CJ); Wheeler v Baldwin (1934) 52 CLR 609, 630 (Dixon J); Fernandes v Houstein (1963) 4 FLR 355, 357-58 (Dunphy J); Galvasteel Pty Ltd $v$ Monterey Building Pty Ltd (1974) 10 SASR 176, 180-81 (Walters J); Jessica Holdings Pty Ltd v Anglican Property Trust Diocese of Sydney (1992) 27 NSWLR 140, 151 (Brownie J); CFHW v Burness [2014] VSC 451 [25] (Warren CJ).

111 Abigail v Lapin [1934] AC 491; (1934) 51 CLR 58, 65 (Lord Wright (on behalf of the Privy Council)); In re Peychers' Caveat [1954] NZLR 285, 286 (Archer J). 


\section{Assignee's Failure to Lodge a Caveat once the Assignor has become the Registered Proprietor}

A further question is what the implications of the assignee failing to lodge a caveat might be once the assignor has become the registered proprietor. More pointedly: will the assignee's failure to lodge a caveat mean that their interest will be postponed to later equitable interests? On the one hand, it might be said that the assignee's failure to lodge a caveat could lead to a loss of priority vis-à-vis later equitable interest holders. This would be commensurate with the view articulated by Callinan $\mathrm{J}$ in Black $v$ Garnock, ${ }^{112}$ namely, that a purchaser having an executory interest in land should ensure their protection by lodging a caveat or risk postponement. ${ }^{113}$ On the other hand, if it is accepted that the assignor holds the land on bare constructive trust for the assignee, then it would seem that the assignee would enjoy a very high degree of protection from later equitable interests, due to the rule in Shropshire Union Railways and Canal Co v The Queen. ${ }^{114}$ The latter provides that a beneficiary will not be postponed because a trustee has created further equitable interests contrary to his or her fiduciary office. Although the rule in Shropshire Union Railways and Canal Co v The Queen ${ }^{115}$ has not been tested in the Torrens context, there are numerous decisions which indicate that absent arming conduct, a first equitable interest holder's failure to lodge a caveat should not lead to automatic postponement. ${ }^{116}$ Moreover, there are certain decisions which have indicated, even if only by way of obiter dicta, that the rule in Shropshire Union Railways and Canal Co $v$ The Queen ${ }^{117}$ would not be negated by a beneficiary's failure to lodge a caveat. ${ }^{118}$

Before concluding the present section, it is apposite to contemplate one further issue, namely, what happens if the assignor of future Torrens land, once becoming the registered proprietor, reneges upon his or her agreement with the assignee and sells the same land to a later second assignee which progresses to settlement but not registration. In all Australian jurisdictions, aside from New South Wales (NSW) and the Australian Capital Territory (ACT), the matter will be decided by the principles of competing equitable interests. This means, in line with the rule in Shropshire Union Railways and Canal Co $v$ The Queen, ${ }^{119}$ that priority would go to the original

112 (2007) 230 CLR 438.

113 Ibid 455.

114 (1875) LR 7 HL 496; See also Cory v Eyre (1863) 1 De GJ \& S 149, 168 (Turner LJ); Shropshire Union Railways and Canal Co $v$ The Queen (1875) LR 7 HL 496, 507-08 (Lord Cairns LC), 511 (Lord Hatherley), 514 (Lord O'Hagan); Bradley v Riches [1876] 9 Ch D 189, 192-93 (Fry J); Carritt v Real and Personal Advance Company (1889) 42 Ch D 263, 270 (Chitty J); Taylor v London and County Banking Co [1901] 2 Ch 231, 260-62 (Stirling LJ (with whom Rigby and Vaughan Williams LJJ agreed)); Burgis $v$ Constantine [1908] 2 KB 484, 503-04 (Farwell LJ); Coleman v London County \& Westminster Bank Ltd [1916] 2 Ch 353, 360 (Neville J); Hill v Peters [1918] 2 Ch 273, 277-78 (Eve J).

115 (1875) LR 7 HL 496.

${ }^{116}$ Glen Anderson, 'Old Meets New: The Rule in Shropshire's Case and the Torrens System' (2014) 4(2) Property Law Review 112-14.

117 (1875) LR 7 HL 496.

118 Glen Anderson, 'Old Meets New: The Rule in Shropshire's Case and the Torrens System' (2014) 4(2) Property Law Review 112-14.

119 (1875) LR 7 HL 496. 
assignee. In NSW and the ACT, however, a different result would potentially follow due to s 43A(1) of the Real Property Act (NSW) and s 60 of the Land Titles Act 1925 (ACT), both of which state:

For the purpose only of protection against notice, the estate or interest in land under the provisions of this Act, taken by a person under a dealing registrable, or which when appropriately signed by or on behalf of that person would be registrable under this Act shall, before registration of that dealing, be deemed to be a legal estate.

This means that provided the second assignee took bona fide for value and without notice of the original assignee's equitable interest, the second assignee would have an unregistered legal interest ${ }^{120}$ and would take priority over the original assignee. The same protection would extend to any sale made by the second assignee in the period post-settlement and preregistration due to the successive effect doctrine articulated in Wilkes $v$ Spooner. ${ }^{121}$ Moreover, such protection would endure even when the new purchaser took with notice of the original assignee's interest under the future land contract. As indicated in Jonray (Sydney) Pty Ltd v Partridge Bros Pty Ltd, ${ }^{122}$ the protection afforded by Wilkes $v$ Spooner ${ }^{123}$ would not apply if the new purchaser was also the original assignor. This is because the doctrine in Wilkes $v$ Spooner ${ }^{124}$ cannot be used to allow a trustee (the original assignor under the future property contract) in breach of trust to sell to a bona fide purchaser for value without notice (second assignee), only to reacquire the legal title and thus defraud the trust's intended beneficiary (original assignee under the future land contract).

${ }^{120}$ Courtenay v Austin [1962] NSWR 296, 311 (Hardie J); IAC (Finance) Pty Ltd v Courtenay (1963) 110 CLR 550, 584-85 (Taylor J); Jonray (Sydney) Pty Ltd v Partridge Bros Pty Ltd (1969) 89 WN (Pt 1) (NSW) 568, 576-77 (Heron CJ, Jacobs and Asprey JJA); Meriton Apartments Pty Ltd v McLaurin \& Tait (Developments) Pty Ltd (1976) 133 CLR 671; 10 ALR 296, CLR 676; ALR 300 (Barwick CJ, Mason and Jacobs JJ); Black v Garnock (2007) 230 CLR 438, 450 (Gummow and Hayne JJ); Westpac Banking Corporation v Ollis [2008] NSWSC 824 [49] (Einstein J); Weller $v$ Williams [2010] NSWSC 716 [16] (Ball J); John Alexander's Clubs Pty Ltd v White City Tennis Club Ltd (2010) 241 CLR 1, 42 (French CJ, Gummow, Hayne, Heydon and Kiefel JJ); Weller v Williams [2010] NSWSC 716 [13][16] (Ball J); Taleb v National Australia Bank Ltd [2011] NSWSC 1562 [40] (Bryson JA); Barlin Investments Pty Ltd v Westpac Banking Corporation [2012] NSWSC 699 [37]-[38] (Ball J); Stone Leaf Capital Pty Ltd v Daly [2014] NSWSC 477 [31]-[32] (White J); Irina Prodger $v$ Trevor William Prodger (No 2) [2015] NSWSC 339 [22] (Slattery J); On the difficulties of interpreting s 43A(1) of the Real Property Act see Commissioner of Taxation v Luxottica Retail Australia Pty Ltd [2011] FCAFC 20 [28]-[29] (Ryan, Stone and Jagot $\mathrm{JJ})$.

121 [1911] 2 KB 473; Also known as the rule in Barrow's case (Re Stapleford Colliery Co (1880) 14 Ch D 432, 445 (Jessel MR)).

122 (1969) 89 WN (Pt 1) (NSW) 568, 577 (Heron CJ, Jacobs and Asprey JJA).

123 [1911] 2 KB 473.

124 Ibid. 


\section{Operation of the In Personam Exception to Torrens Indefeasibility in the Event that the Assignor Refuses to Honour the Contract}

The in personam ${ }^{125}$ exception to Torrens indefeasibility concerns claims that are made against a registered proprietor of land. ${ }^{126}$ As the name of the exception suggests, it essentially concerns rights in personam or between parties, ensuring that a registered proprietor cannot use indefeasibility of title to avoid legal or equitable obligations. ${ }^{127}$ An in personam claim is typically created by a registered proprietor either ante or post registration ${ }^{128}$ and can also be created by a proprietor's agents or employees. ${ }^{129}$ If registration is passed to a new proprietor unrelated to the in personam claim, then the new proprietor will not be bound, as the claim will not operate in rem. ${ }^{130}$ In the majority of Australian jurisdictions, there is no legislative provision which refers to the in personam exception to indefeasibility. ${ }^{131}$ Nonetheless, the exception undeniably exists. In Barry $v$ Heider ${ }^{132}$ for example, Griffith CJ stated that the Torrens system in no way destroyed,

125 The in personam exception to indefeasibility is also referred to as a 'personal equity', 'right in person', 'equitable obligation' and 'equitable right'. It is submitted that any explicit reference to equity with regards to this exception to indefeasibility can be misleading, as not all in personam claims have an equitable origin (although most do). The phrase 'in personam', which coincidently is the most popular label, is therefore henceforth applied. On the foregoing terminological and conceptual issues, see Peter Butt, Land Law (Lawbook Co, $6^{\text {th }}$ ed, 2010) 819; Kelvin FK Low, 'The Nature of Torrens Indefeasibility: Understanding the Limits of Personal Equities' (2009) 33 Melbourne University Law Review 208.

${ }^{126}$ On the exception generally, see Peter Butt, Land Law (Lawbook Co, $6^{\text {th }}$ ed, 2010) 818; Brendan Edgeworth, Peter Butt's Land Law (Lawbook Co, $7^{\text {th }}$ ed, 2017) 874; Anthony P Moore, Scott Grattan and Lynden Griggs, Australian Real Property Law (Lawbook Co, $6^{\text {th }}$ ed, 2016) 257.

${ }^{127}$ On the requirement of a known legal or equitable obligation see Farah Constructions Pty Ltd v Say-Dee Pty Ltd [2007] 230 CLR 89, 169 (Gleeson CJ, Gummow, Callinan, Heydon and Crennan JJ); Macquarie Bank Ltd v Sixty Fourth Throne Pty Ltd [1998] 3 VR 133, 146-147 (Tadgell JA (with whom Winneke P agreed)), 162 (Ashley AJA); Sino Iron Pty Ltd v Worldwide Wagering Pty Ltd [2017] VSC 101 [394]-[395] (Hargrave J); Anderson $\checkmark$ Anderson [2017] NSWCA 131 [50] (Leeming JA (with whom Basten JA and Sackville AJA agreed)).

${ }^{128}$ Logue v Shoalhaven Shire Council [1979] 1 NSWLR 537, 563 (Mahoney JA); Bahr v Nicolay (No 2) (1988) 164 CLR 604, 613 (Mason CJ and Dawson J), 638 (Wilson and Toohey JJ); Grgic v Australian and New Zealand Banking Group (1994) 33 NSWLR 202, 222-23 (Powell JA (with whom Meagher and Handley JJA agreed)); Minister for Education and Training v Canham [2004] NSWSC 274 [47] (Pearlman AJ); Ciaglia v Ciaglia [2010] NSWSC 341 [113] (White J); Body Corporate No 12870 v Aldal [2010] VSC 366 [108] (Vickery J).

${ }^{129}$ Grgic v Australian and New Zealand Banking Group (1994) 33 NSWLR 202, 222-23 (Powell JA (with whom Meagher and Handley JJA agreed)); White v Tomasel [2004] QCA 89 [24] (Davies JA); Spina v Conran Associates Pty Ltd; Spina v M \& V Endurance Pty Ltd [2008] NSWSC 326 [97]-[98] (Austin J); Refina Pty Ltd v Binnie [2009] NSWSC 914 [35] (Brereton J).

${ }^{130}$ S Robinson, 'Claims In Personam in the Torrens System: Some General Principles' (1993) 67 Australian Law Journal 355; Tang Hang Wu, 'Beyond the Torrens Mirror: A Framework of the In Personam Exception to Indefeasibility' (2008) 32 Melbourne University Law Review 680.

${ }^{131}$ In Queensland and South Australia, the in personam exception to indefeasibility is mentioned in s 185(1)(a) of the Land Title Act 1994 (QLD) and s 71(d) and (e) of the Real Property Act 1886 (SA).

132 (1914) 19 CLR 197. 
'the fundamental doctrines by which Courts of Equity have enforced, as against registered proprietors, conscientious obligations entered into by them. ${ }^{133}$ Likewise, in Frazer $v$ Walker, ${ }^{134}$ Lord Wilberforce observed that Torrens indefeasibility 'in no way denies the right of a plaintiff to bring against a registered proprietor a claim in personam, founded in law or equity, for such relief as a court acting in personam may grant.' ${ }^{135}$ Other cases have made similar comments. ${ }^{136}$

In circumstances where the assignor of future Torrens land has agreed for valuable consideration to sell the land to the assignee, but then later reneges upon the agreement and instead remains the registered proprietor, an in personam claim would arise. This new claim-failure to assure future Torrens land - draws inferential support from two closely related equitable analogues: the right of a purchaser to specific performance and the right of a beneficiary to compel the trust against a trustee.

\section{A Purchaser's Right to Specific Performance}

It was established very soon after the inception of the Torrens system that a purchaser can seek specific performance from the vendor in relation to an executory contract for the sale of land, notwithstanding the vendor's

133 Ibid 213

134 [1967] 1 AC 569.

135 Ibid 585 (Lord Wilberforce (on behalf of the Privy Council)) (emphasis added).

${ }^{136}$ Maddison v McCarthy (1865) 2 WW \& aB (Eq) 151; Paoro Torotoro v Sutton (1877) 1 NZ JR NS SC 57, 65 (Prendergast CJ); Cuthbertson v Swan (1877) 11 SALR 102, 109 (Stow J (with whom Way CJ agreed)); Oh Hiam v Tham Kong (1980) BPR 9451, 9454 (Lord Russell of Killowen (on behalf of the Privy Council)); Mercantile Mutual Life Insurance Co Ltd v Gosper (1991) 25 NSWLR 32, 43 (Mahoney JA); Groongal Pastoral Co Ltd v Falkiner (1924) CLR 157, 163 (Isaacs ACJ, Gavan Duffy and Starke JJ); Breskvar $v$ Wall (1971) 126 CLR 376, 384-85 (Barwick CJ (with whom Owen J agreed)); Logue v Shoalhaven Shire Council (1979) 1 NSWLR 537, 563 (Mahoney JA); Bahr v Nicolay (No 2) (1988) 164 CLR 604, 613 (Mason CJ and Dawson J), 637-38 (Wilson and Toohey JJ), 653-54 (Brennan J); Heggies Bulkhaul Ltd v Global Mineral Australia Pty Ltd [2003] NSWSC 851 [96] (Austin J); Hillpalm Pty Ltd v Heaven's Door Pty Ltd (2004) 220 CLR 472, 491 (McHugh ACJ, Hayne and Heydon JJ); Ryan v Starr [2005] NSWSC 170 [84] (White J); White v Tomasel [2004] QCA 89 [57] (Williams JA), [70] (McMurdo J); Farah Constructions Pty Ltd v Say-Dee Pty Ltd [2007] 230 CLR 89, 169 (Gleeson CJ, Gummow, Callinan, Heydon and Crennan JJ); Harris v Smith [2008] NSWSC 545 [56] (Brereton J); Spina v Conran Associates Pty Ltd [2008] NSWSC 326 [94]-[97] (Austin J); Perpetual Trustees Victoria Ltd v Cipri [2008] NSWSC 1128 [97] (Hall J); White City Tennis Club Ltd v John Alexander's Clubs Pty Ltd [2008] NSWSC 1225 [100] (Macfarlan JA); Bonfinger v Kingsway Group Ltd (2009) 239 CLR 269, 282 (Gummow, Hayne, Heydon, Kiefel and Bell JJ); Westpac Banking Corporation v Dunn [2011] WASC 7 [9] (Le Miere J); Residential Housing Corporation v Esber [2011] NSWCA 25 [56] (Campbell JA (with whom Macfarlan JA and Sackville AJA agreed)); Castle Constructions Pty Ltd v Sahab Holdings Pty Ltd (2013) 247 CLR 149, 163 (Hayne, Crennan, Kiefel and Bell JJ); Simmons $\checkmark$ New South Wales Trustee and Guardian [2014] NSWCA 405 [70] (Gleeson JA (with whom Beazley P and Barrett JA agreed)); Sze Tu v Lowe [2014] NSWCA 462 [224] (Gleeson JA (with whom Meagher and Barrett JJA agreed)); Despot v Registrar General of New South Wales [2016] NSWCA 5 [164] (Gleeson JA (with whom Leeming JA and Sackville AJA agreed)); Sino Iron Pty Ltd v Worldwide Wagering Pty Ltd [2017] VSC 101 [394]-[395] (Hargrave J). 
indefeasibility of title. ${ }^{137}$ Put alternatively, the fact that the vendor is the registered proprietor cannot be raised as a defence against the remedy of specific performance. ${ }^{138}$ Although the assignment of future property does not depend on a court's order of specific performance, ${ }^{139}$ cases sourced from the general domain of specific performance in the Torrens context do establish that an assignment of future Torrens land cannot be negated by the assignor's indefeasibility of title.

\section{A Beneficiary's Right to Compel the Trust Against a Trustee}

Another in personam claim which is closely related to the failure to assure future Torrens land is the ability of a beneficiary to compel the trust against a trustee who is the registered proprietor: the trustee cannot refuse to transfer the land claiming indefeasibility of title. ${ }^{140}$ In Boyd v Mayor, etc, of Wellington, ${ }^{141}$ for example, Adams J noted that ' $[\mathrm{t}]$ he power of the Court to enforce trusts, express or implied ... has been repeatedly exercised.' ${ }^{142}$ It follows that the same claim might also be applied in the context of a failure to assure future Torrens land. This stems from the fact that the assignor of future land is, upon taking the registered title, regarded as a bare constructive trustee for the assignee. ${ }^{143}$ This means that the assignor will be

${ }^{137}$ LL Stevens, 'The In Personam Exceptions to the Principle of Indefeasibility' (1969) 1(2) Auckland University Law Review 41; Peter Butt, Land Law (Lawbook Co, $6^{\text {th }}$ ed, 2010) 819.

${ }^{138}$ Maddison v McCarthy (1865) 2 WW \& AB (Eq) 151; Paoro Torotoro v Sutton (1877) 1 NZ JR NS SC 57, 65 (Prendergast CJ); Cuthbertson v Swan (1877) 11 SALR 102, 109 (Stow J (with whom Way CJ agreed)); Barry v Heider (1914) 19 CLR, 197, 213 (Griffith CJ); Oh Hiam v Tham Kong (1980) BPR 9451, 9454 (Lord Russell of Killowen (on behalf of the Privy Council)); Mercantile Mutual Life Insurance Co Ltd v Gosper (1991) 25 NSWLR 32, 43 (Mahoney JA).

139 Re Lind; Industrials Finance Syndicate Limited v Lind [1915] 2 Ch 345, 356-66 (Phillimore LJ); Palette Shoes Pty Ltd (in liquidation) v Krohn (1937) 58 CLR 1, 27 (Dixon J); McIntyre v Gye (1994) 122 ALR 289, 296-97 (Davies, Burchett and Gummow JJ); Booth v Federal Commissioner of Taxation (1987) 164 CLR 159, 165 (Mason CJ); Deputy Commissioner of Taxation v Bluebottle UK Ltd [2006] NSWCA 360 [25] (Santow JA (with whom Mason $\mathrm{P}$ agreed)).

${ }^{140}$ Oh Hiam v Tham Kong (1980) 2 BPR 9451, 9454 (Lord Russell of Killowen (on behalf of the Privy Council)); Sistrom v Uhr (1992) 40 FCR 550, 557-58 (Davies, Ryan and von Doussa JJ).

141 [1924] NZLR 1174.

142 Ibid 1223.

${ }^{143}$ Legard v Hodges (1792) 1 Ves Jun 478 (Lord Thurlow LC); In Re Gillott's Settlement; Chattock v Reid [1934] 1 Ch 97, 108-09 (Maugham J); Bakewell v Deputy Federal Commissioner of Taxation (SA) (1937) 58 CLR 743, 761-62 (Starke J); Visbord v Federal Commissioner of Taxation (1943) 68 CLR 344, 383 (Williams J); Federal Commissioner of Taxation v Everett (1978) 21 ALR 625, 644 (Deane J); Federal Commissioner of Taxation v Everett (1980) 143 CLR 440, 450 (Barwick CJ, Stephen, Mason and Wilson JJ); Booth v Federal Commissioner of Taxation (1987) 164 CLR 159, 165 (Mason CJ), 178 (Toohey and Gaudron JJ); Hadlee v Commissioner of Inland Revenue [1991] 3 NZLR 517, 520 (Cooke P (with whom Casey and Hardie Boys JJ and Sir Gordon Bisson agreed)), 527 (Richardson J (with whom Casey and Hardie Boys JJ and Sir Gordon Bisson agreed)); Bluebottle UK Ltd v Deputy Commissioner of Taxation [2006] NSWSC 706 [60] (Gzell J); Deputy Commissioner of Taxation v Bluebottle UK Ltd [2006] NSWCA 360 [25]-[26] (Santow JA (with whom Mason P agreed)); RIL Aviation HL 7740 and HL 7741 Pty Ltd $v$ Alliance \& Leicester plc [2011] NSWCA 423 [206]-[207] (Young JA); Commissioner of 
required to transfer the registered title to the assignee forthwith, and that the indefeasibility provisions of Torrens legislation will be no barrier to this process.

\section{A New In Personam Claim}

Notwithstanding the two analogues mentioned above, the right of an assignee of future Torrens land to compel the transfer would, stricto sensu, be a new in personam claim (failure to assure future Torrens land). It is submitted that there would be no barrier to the recognition of this new claim. The assignment of future property is founded in equity and thus conforms with the requirement of a 'known legal or equitable cause of action.' 144

\section{Conclusion}

Although the basic parameters surrounding the assignment of future property are well settled, no comprehensive guidance has been provided by courts on how these might apply to the Torrens system. Despite this, the assignment of future land is readily subsumable within the Torrens system.

Although the assignee of future Torrens land is, prior to receiving the assignment from the assignor, unable to register their interest, they can, once the assignor has become the registered proprietor (and bare constructive trustee), lodge a caveat to protect their equitable interest. In the event that the assignee fails to lodge a caveat to protect their equitable interest, the rule in Shropshire Union Railways and Canal Co $v$ The Queen ${ }^{145}$ would provide strong protection in a priority dispute against any later equitable interests. ${ }^{146}$ This protection could be negated in NSW and the ACT, however, when the later interest falls under s 43A(1) of the Real Property Act 1900 (NSW) or s 60 of the Land Titles Act 1925 (ACT).

In circumstances where the assignor of future Torrens land reneges upon his or her agreement with the assignee and attempts to remain the registered proprietor, the in personam exception to indefeasibility would be available

State Revenue v Abbotts Exploration Pty Ltd [2014] WASCA 211 [210] (Murphy JA); Lotteries Pty Ltd v Volteas [2015] VSCA 226 [38] (Whelan JA (with whom Ferguson and McLeish JJA agreed)).

144 Horvath v Commonwealth Bank of Australia [1998] VSCA 51 [17] (Tadgell JA); Macquarie Bank Ltd v Sixty-Fourth Throne Pty Ltd [1998] 3 VR 133, 162 (Ashley AJA); Minister for Education and Training v Canham [2004] NSWSC 274 [47] (Pearlman AJ); White v Tomasel [2004] QCA 89 [70] (McMurdo J); Vella v Permanent Mortgages Pty Ltd [2008] NSWSC 505 [375] (Young CJ in Eq); Refina Pty Ltd v Binnie [2009] NSWSC 914 [35] (Brereton J); Capital Finance Aust Ltd v Pella Properties Pty Ltd [2010] NSWSC 1262 [111] (Kirby J); Dixon v Barton [2011] NSWSC 1525 [75] (Ward J); Rasch Nominees Pty Ltd v Bartholomaeus [2012] SASC 70 [234] (Kourakis J); Lord v McMahon [2015] NSWSC 1619 [244] (Slattery J); Smilevska v Smilevska (No 2) [2016] NSWSC 397 [131] (Slattery J); Sino Iron Pty Ltd v Worldwide Wagering Pty Ltd [2017] VSC 101 [394] (Hargrave J).

145 (1875) LR 7 HL 496.

${ }^{146}$ Glen Anderson, 'Old Meets New: The Rule in Shropshire's Case and the Torrens System' (2014) 4(2) Property Law Review 112-14. 
to the assignee to enforce the assignor's conscientious obligations. Technically, this would be a new in personam claim: failure to assure future Torrens land.

Should the assignor of future Torrens land sell not to the original assignee, but to a new assignee who becomes the registered proprietor, indefeasibility of title will mean that the original assignee will only be left with contractual recourse against the assignor for breach of contract.

Although it might be surmised that Robert Torrens would lament the incorporation of 'prophetic conveyances' ${ }^{147}$ within the system of 'title by registration' ${ }^{148}$ which he helped to create, it is apparent that there is a place for future land contracts within that system. Equity's pre-modern jurisdiction and the relatively contemporary Torrens system can work together to give effect to future land transactions.

${ }^{147}$ Belding v Read (1865) 3 H \& C 995, 961 (Pollock CB).

${ }^{148}$ Breskvar v Wall (1971) 126 CLR 376, 385 (Barwick CJ (with whom Owen J agreed)). 